\title{
NEURAL NETWORK FORECASTING OF DEMAND AND SUPPLY IN THE LABOR MARKET OF UKRAINE BY TYPES OF ECONOMIC ACTIVITY
}

\author{
N. Mishchuk, S. Pryima \\ Ivan Franko National University of Lviv \\ 79008, Lviv, Svoboda Avenue, 18 \\ e-mail: mishchuk_n@ukr.net,sv_pryyma@ukr.net
}

\begin{abstract}
The article examines new approaches to labor market regulation, in particular, research and forecasting labor supply and demand by type of economic activity. And it is also investigated that the imbalance between supply and demand in the labor market is observed in almost all types of economic activity. Has been established significance of the influence of seasonal factor on the processes of economic activity of the population. Using neural networks, obtained the predictive values of employment and unemployment in the labor market of Ukraine by types of economic activity based on data from the State Employment Service.

Keywords: labor market, employment, unemployment, forecasting, neural network, management.
\end{abstract}

The problem. The social changes that take place in the conditions of functioning of the information economy of Ukraine, the socio-political and economic situation in the country affect the structure of the national labor market. Such transformations require new approaches to regulating the labor market, including a comprehensive study of supply and demand of labor. The relevance of the study is due to the fact that the labor market is a dynamic and difficult-to-predict system, and therefore the use of neural networks to predict the structure of the labor market can be an effective means of regulating the development of this economy sector.

Analysis of recent research and publications. The study of problems of forecasting and development of the labor market has been devoted to domestic and foreign scientists, namely: J. Grayson, M. Campbell, M. Merzlova, O. Stretskaya-Illina, K. O'Dell, P. McConnell. Interesting are the works of domestic economists, in particular V. V. Bliznyuk [1], V. V. Druzhinina, A. Ivanchenko, G. I. Kupalova, O. M. Levchenko, L. S. Lysogor [2], Yu. M. Marshavina, L. E. Lamina, V. I. Priymak [3], O. I. Cymbal and others. However, the features of forecasting the development of the labor market, in particular, the forecasting of the needs of the economy in the labor force and the volume of vacancies for employment by type of economic activity, remain poorly understood.

Setting objectives. The purpose of this study is to summarize approaches to forecasting supply and demand in the labor market of Ukraine, as well as to conduct a neural network forecasting of the number of unemployed and the number of vacancies by types of economic activity.

The main material. Transformation of socio-economic relations in the current globalization conditions cause structural changes in the labor market of Ukraine. Increased

(C) N. Mishchuk, S. Pryima, 2019 
competition, the development of the knowledge economy, information technology, changes in the content and forms of labor require updating the system of regulation of the labor market.

For Ukraine internal factors of socio-economic instability related to:

- $\quad$ increasing social tension in society by reducing living standards;

- worsening employment conditions, territorial and vocational-qualitative imbalances between labor market demand and supply;

- aggravation of the situation in regional labor markets.

Among the tools for regulating the labor market, the most promising are those that take into account the objective impact of global factors and aim to increase motivation for work; activation of innovative employment and entrepreneurial activity of the population; ensuring the balance of the education services market and the labor market; forecasting and planning the structure of supply and demand in the labor market; increasing the competitiveness of specialists and expanding the range of decent jobs. [4, p. 20].

In order to evaluate the efficiency of regulation and development of the labor market in the information economy, it is advisable to use different groups of indicators and indices, in particular: research of economically active population; research of supply and demand in the labor market; research on wages; surveys of the unemployed; employment survey; study of the social status of the population. An integral part of this process is forecasting, which is difficult to overestimate. According to [5, p. 261], in order for labor market management to be effective, it is not enough to know its present state and how this state has changed in the past. Information on the future trajectory of this market is needed. That is, together with the assessment of the state and dynamics of the labor market, it is necessary to have a forecast of demand, supply and other characteristics of this market. This issue is of particular relevance in view of today's active deployment of computerized decision support systems.

Choosing a prediction technique affects the accuracy and quality of the prediction results. Data that is collected and used to make forecasts is often represented as time series that describe the evolution of the process over time. Therefore, forecasting is usually related to time series analysis.

The surveyed series of data on the number of vacancies and the number of persons who had the status of unemployed consist of observations for three years, monthly from January 2016 to February 2019. We believe that the number of vacancies and unemployed persons for the next month depends on the number of previous months.

In our opinion, the labor market of Ukraine is characterized by inertia, and therefore we believe that in the future it will continue to develop in accordance with the laws under which it developed in the past and exists today. To forecast the demand and supply in the labor market of Ukraine by types of economic activity, it is necessary to build a mathematical model, check the degree of its adequacy and correctly apply it to the existing observations. Such a model should explain the essence of the process that generates the data, in particular - to describe the nature of the data (random, periodic, stationary, etc.), identify patterns of behavior of the series, as well as to predict its further development.

The correlation analysis showed that for the studied series of data on the number of persons who had the status of unemployed and the number of vacancies registered with the State Employment Service by type of economic activity, the autocorrelation coefficients for the shift values are large, which indicates the presence of a seasonal component with an annual frequency. 
The input factors of the model for forecasting the number of unemployed and the number of vacancies will be considered the number of persons for the current month, the month before and so on, and the result - the number of persons for the next month.

To build a predictive model for the number of unemployed and job vacancies, need to know the following options:

- forecast interval - the time interval at which forecasting will be made;

- forecast horizon - how many intervals do we want to get the forecast for;

- depth of immersion - the number of interval values in the past that we will use to predict interval values in the future.

For the forecast of the number of persons who will have the status of unemployed and the number of jobs in the labor market by type of economic activity for August-October 2019 neural network apparatus was chosen, since neural networks allow to simulate linear and nonlinear dependencies, have the ability to generalize and isolate hidden dependencies between incoming and source data.

Any kind of dependency $x t=f\left(x t \_l, x t_{-} 2, \ldots, x t \_p\right)+e t$ with continuous nonlinear function it can be reproduced on a multilayer network, namely a two-layer perceptron (Fig. 1)..

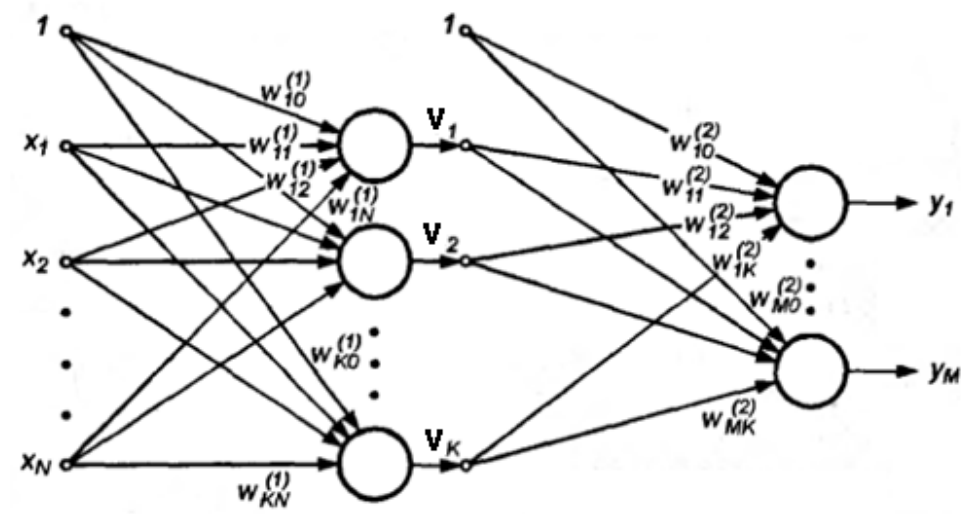

Fig. 1. Generalized structure of a two-layer sigmoid neural network (with one hidden layer) $[6]$

Where the weights of the hidden layer neurons are indicated by the upper index (1) and the initial index (2), $x=[x 0, x 1, \ldots, x N] \mathrm{T}$ - input vector, $\mathrm{vj}(\mathrm{j}=1,2, \ldots, \mathrm{K})$ - the output signals of the hidden layer neurons, $\mathrm{y}=[\mathrm{y} 0, \mathrm{y} 1, \ldots, \mathrm{yM}] \mathrm{T}-$ vector of actual output signals, $\mathrm{d}=[\mathrm{d} 0, \mathrm{x} 1, \ldots, \mathrm{dM}] \mathrm{T}-$ vector of expected output signals.

The purpose of training is in the selection of such values wij(1) i wij(2) weights for all layers of the network to obtain the output values of the signals yi at a given input vector $\mathrm{x}$, which will match the values with the right accuracy di $(i=1,2, \ldots, M)$.

The output signal of the ith neuron of the hidden layer is described by the function function $v_{j}=f\left(\sum_{j=0}^{N} w_{i j}^{(1)} x_{j}\right)$

In the output layer, the k-neuron generates an output signal: 


$$
y_{k}=f\left(\sum_{i=0}^{K} w_{k i}^{(2)} v_{i}\right)=f\left(\sum_{i=0}^{K} w_{k i}^{(2)} f\left(\sum_{j=0}^{N} w_{i j}^{(1)} x_{j}\right)\right)
$$

The output signal is influenced by the weights of both layers, but the hidden layer signals are independent of the weights of the output layer.

In order to predict future values using neural networks, it is necessary to prepare data for training and testing of the network operation, to select the topology, basic characteristics and parameters of training of the neural network.

Table 1

Neural networks to predict the number of people who have been unemployed by the types of economic activity of enterprises they previously worked for

\begin{tabular}{|c|c|c|c|}
\hline $\begin{array}{c}\text { Type of economic activity of } \\
\text { enterprises }\end{array}$ & Chain & Error on training set & Error on test set \\
\hline agriculture, forestry and fisheries & $4-5-1$ & 1344E-05 & $2,86 \mathrm{E}-04$ \\
\hline mining and quarrying & $4-6-1$ & $2,05 \mathrm{E}-06$ & $1,41 \mathrm{E}-03$ \\
\hline manufacturing industry & $4-5-1$ & $3,08 \mathrm{E}-06$ & $1,30 \mathrm{E}-03$ \\
\hline $\begin{array}{l}\text { supply of electricity, gas, steam and air } \\
\text { conditioning }\end{array}$ & $4-5-1$ & $2,05 \mathrm{E}-06$ & $9,21 \mathrm{E}-04$ \\
\hline $\begin{array}{l}\text { water supply; sewerage, waste } \\
\text { management }\end{array}$ & $4-6-1$ & $2,01 \mathrm{E}-05$ & $1,30 \mathrm{E}-03$ \\
\hline construction & $4-4-1$ & $5,20 \mathrm{E}-06$ & $1,48 \mathrm{E}-03$ \\
\hline $\begin{array}{l}\text { wholesale and retail trade; repair of } \\
\text { motor vehicles and motorcycles }\end{array}$ & $4-5-1$ & $5,31 \mathrm{E}-06$ & $7,44 \mathrm{E}-04$ \\
\hline $\begin{array}{l}\text { transport, warehousing, postal and } \\
\text { courier activities }\end{array}$ & $4-5-1$ & $8,41 \mathrm{E}-05$ & $1,24 \mathrm{E}-03$ \\
\hline temporary accommodation and catering & $4-2-1$ & $6,24 \mathrm{E}-04$ & 3,09 E-03 \\
\hline information and telecommunications & $4-5-1$ & 3,71 E-06 & $3,10 \mathrm{E}-032$ \\
\hline financial and insurance activities & $4-5-1$ & $2,20 \mathrm{E}-06$ & 4,90 E-03 \\
\hline real estate operations & $4-21$ & $6,14 \mathrm{E}-05$ & $5,70 \mathrm{E}-04$ \\
\hline $\begin{array}{l}\text { professional, scientific and technical } \\
\text { activities }\end{array}$ & $4-3-1$ & $1,41 \mathrm{E}-05$ & 3,04 E-03 \\
\hline $\begin{array}{l}\text { activities in the field of administrative } \\
\text { and support services }\end{array}$ & $4-3-1$ & $3,45 \mathrm{E}-04$ & $2,71 \mathrm{E}-03$ \\
\hline $\begin{array}{l}\text { public administration and defense; } \\
\text { compulsory social insurance }\end{array}$ & $4-6-1$ & $1,02 \mathrm{E}-07$ & $1,11 \mathrm{E}-02$ \\
\hline education & 4-7-1 & $6,81 \mathrm{E}-05$ & $1,30 \mathrm{E}-04$ \\
\hline health care and social assistance & $4-5-1$ & $4,62 \mathrm{E}-07$ & $5,03 \mathrm{E}-03$ \\
\hline $\begin{array}{l}\text { arts, sports, entertainment and } \\
\text { recreation }\end{array}$ & $4-3-1$ & $2,92 \mathrm{E}-05$ & $1,02 \mathrm{E}-03$ \\
\hline provision of other services & $4-3-1$ & $6,29 \mathrm{E}-04$ & 4,09 E-03 \\
\hline
\end{tabular}

The process of forecasting using a neural network can be represented in the form of 6 stages $[7$, p. 123]:

1) statement of the task - it is necessary to clearly define what we need to anticipate and what data to use;

2) collection and preparation of raw data - obtaining information from available sources, determining the format of information presentation, creating a sample database for training and testing of the neural network; 
3) creating a neural network -- determining its topology, inputs, outputs, the number of hidden layers and the number of neurons in each of them;

4) network training (if the network cannot learn, steps 2 and 3 need to be repeated);

5) network testing - checking the accuracy of the network on test samples (if the test results are unsatisfactory, steps 2,3 and 4 are repeated);

6) obtaining predictive values.

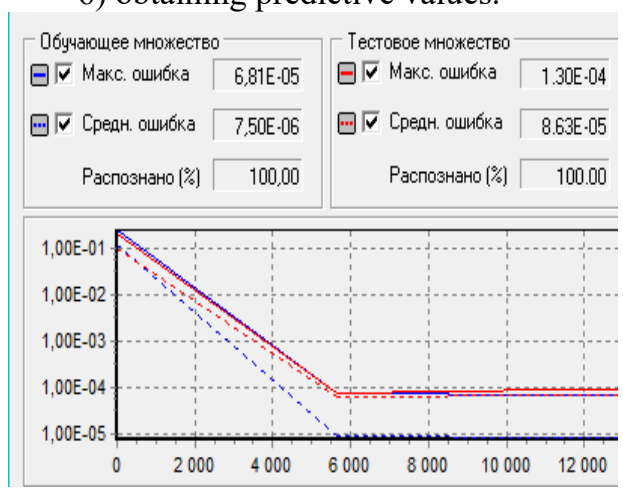

Fig. 2. Neural Network Training

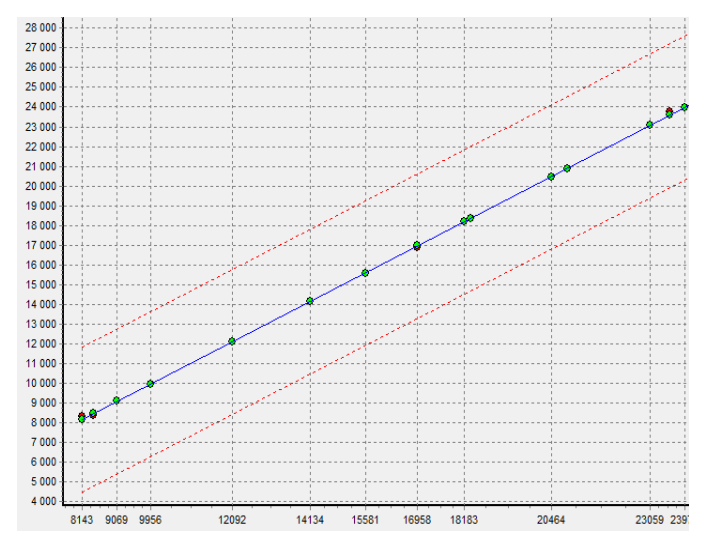

Fig. 3. Scatter Chart

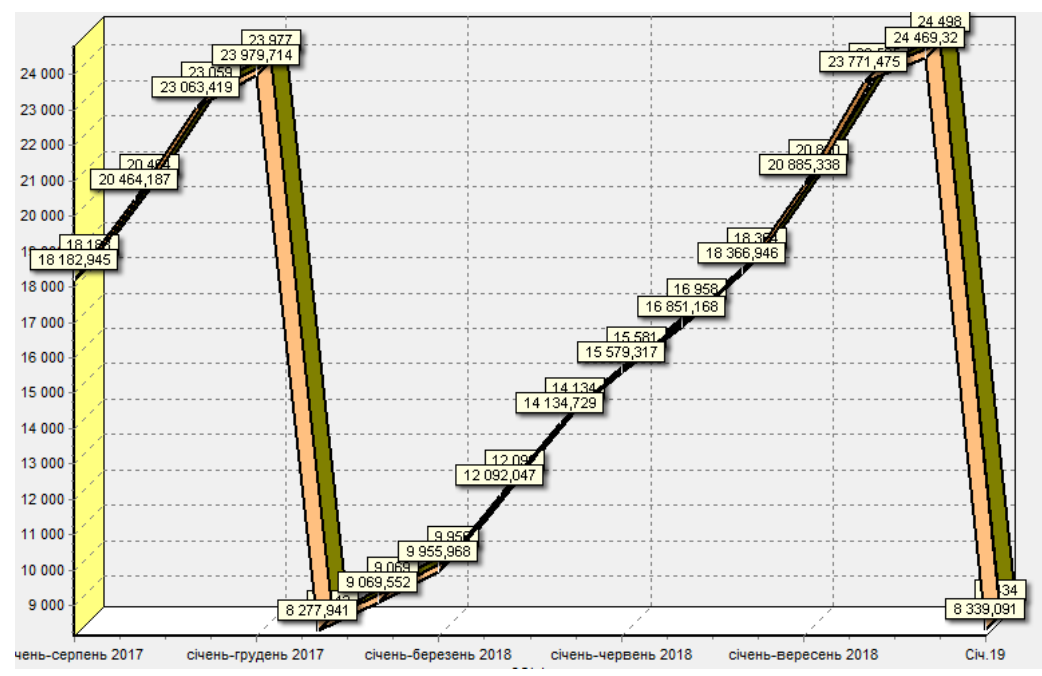

Fig. 4. Comparison of projected data with reference data

To construct a model of forecasting the number of persons who had the status of unemployed, registered in the state employment service for each type of economic activity, the neural networks of the respective structure were selected (Table 1). For example, MLP 4-7-1 (4 input, 7 hidden and 1 output neurons) with a sigmoid activation function was built to predict the number of people who were unemployed in education. The three-layer multilayer perceptron is taken as the base model. The training was conducted by the 
Resilient propagation method. The neural network training schedule and the percentage of recognized examples for education are shown in Fig. 2.

The network recognizes $100 \%$ of the examples, the magnitude of the error on the training set $6,81 \mathrm{E}-05$, and on the test set 1,30E-04. The scatterplot (Fig. 3) shows the scattering of the forecast data relative to the reference ones. Comparison of the predicted values with the reference values (Fig. 4) shows slight deviations between the initial and the predicted data. Overall, the quality of network training is satisfactory.

Estimated values of the number of persons who had the status of unemployed in education for August-October 2019 in Fig. 5.

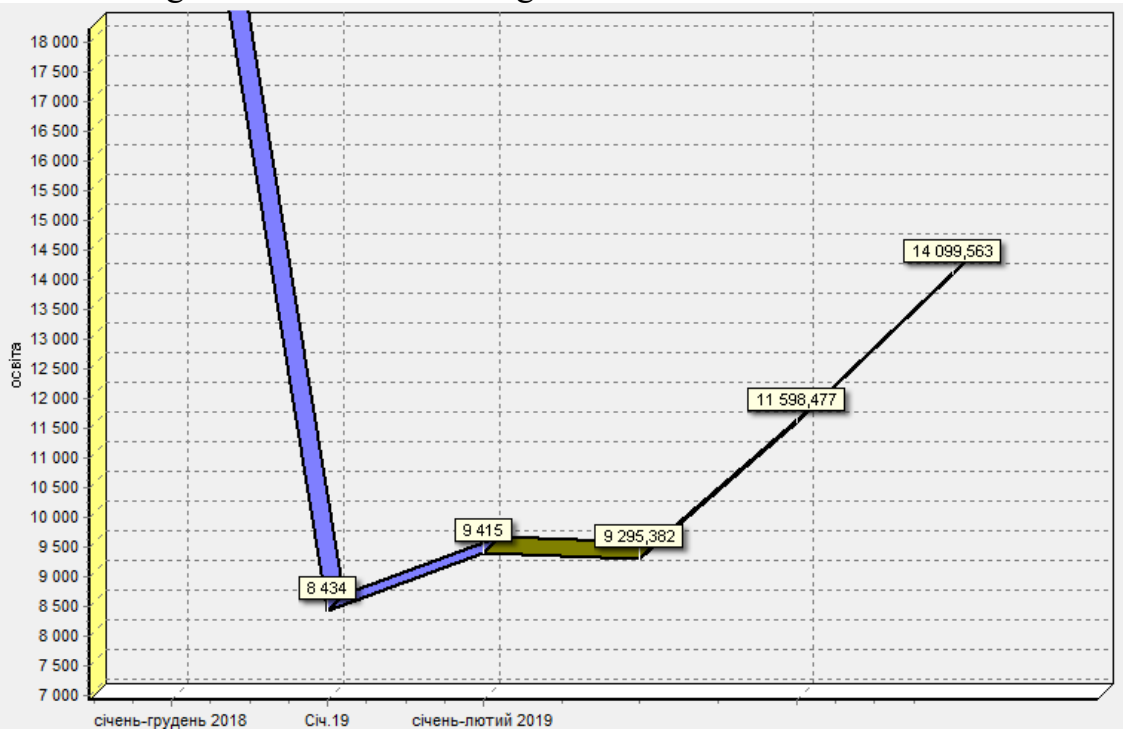

Fig. 5. Estimated values of the number of people who were unemployed in education for March-May 2019

The study found that in 2019, compared to the same periods in 2018, the number of persons who had the status of unemployed in the educational sector decreased in January-May by 152 persons (1.06\%), in January-June - by 101 persons $(0.64 \%)$, in January-July - 93 persons $(0.55 \%)$. According to the forecast values in 2019, compared to 2018, the number of persons having the status of unemployed will increase by 5579 persons (36.44 \%), while in January-August and January-October it will decrease by 2534 persons (12.13\%) and 879 people (3.59\%) respectively.

To build a model for forecasting the number of vacancies registered with the State Employment Service for each type of economic activity, the neural networks of the respective structure were also selected (Table 2).

Comparison of the number of persons who had the status of unemployed and the number of vacancies registered with the State Employment Service in the educational sector revealed an imbalance between supply and demand during the years studied (Fig. 6). The number of vacancies registered with the State Employment Service is much higher than the number of registered unemployed, although at present the problem of youth unemployment is acute. 
Neural networks to predict the number of jobs registered with the State Employment Service for each type of economic activity

\begin{tabular}{|c|c|c|c|}
\hline $\begin{array}{l}\text { Type of economic activity of } \\
\text { enterprises }\end{array}$ & Chain & Error on training set & Error on test set \\
\hline agriculture, forestry and fisheries & $4-5-1$ & $2,51 \mathrm{E}-05$ & $2,31 \mathrm{E}-04$ \\
\hline mining and quarrying & $4-6-1$ & $2,24 \mathrm{E}-05$ & $1,14 \mathrm{E}-03$ \\
\hline manufacturing industry & $4-5-1$ & $3,56 \mathrm{E}-05$ & $1,92 \mathrm{E}-03$ \\
\hline $\begin{array}{l}\text { supply of electricity, gas, steam and air } \\
\text { conditioning }\end{array}$ & $4-4-1$ & $5,49 \mathrm{E}-04$ & $2,70 \mathrm{E}-03$ \\
\hline $\begin{array}{l}\text { water supply; sewerage, waste } \\
\text { management }\end{array}$ & $4-4-1$ & $1,24 \mathrm{E}-04$ & $2,03 \mathrm{E}-03$ \\
\hline construction & 4-4-1 & $1,04 \mathrm{E}-04$ & $2,81 \mathrm{E}-03$ \\
\hline $\begin{array}{l}\text { wholesale and retail trade; repair of } \\
\text { motor vehicles and motorcycles }\end{array}$ & $4-5-1$ & $1,01 \mathrm{E}-05$ & 5,03 E-039 \\
\hline $\begin{array}{l}\text { transport, warehousing, postal and } \\
\text { courier activities }\end{array}$ & $4-6-1$ & $1,40 \mathrm{E}-05$ & $1,46 \mathrm{E}-05$ \\
\hline temporary accommodation and catering & $4-4-1$ & $3,31 \mathrm{E}-06$ & $130 \mathrm{E}-03$ \\
\hline information and telecommunications & $4-6-1$ & $1,16 \mathrm{E}-06$ & $9,03 \mathrm{E}-04$ \\
\hline financial and insurance activities & $4-8-1$ & $3,25 \mathrm{E}-06$ & $8,14 \mathrm{E}-04$ \\
\hline real estate operations & 4-6-1 & $2,52 \mathrm{E}-05$ & $2,26 \mathrm{E}-03$ \\
\hline $\begin{array}{l}\text { professional, scientific and technical } \\
\text { activities }\end{array}$ & $4-6-1$ & 3,38 E-06 & $5,04 \mathrm{E}-04$ \\
\hline $\begin{array}{l}\text { activities in the field of administrative } \\
\text { and support services }\end{array}$ & $4-6-1$ & $1,53 \mathrm{E}-07$ & $1,35 \mathrm{E}-03$ \\
\hline $\begin{array}{l}\text { public administration and defense; } \\
\text { compulsory social insurance }\end{array}$ & $4-5-1$ & $2,10 \mathrm{E}-06$ & $2,45 \mathrm{E}-03$ \\
\hline education & 4-3-1 & $5,59 \mathrm{E}-05$ & $1,04 \mathrm{E}-03$ \\
\hline health care and social assistance & 4-4-1 & $1,81 \mathrm{E}-05$ & $6,54 \mathrm{E}-03$ \\
\hline $\begin{array}{l}\text { arts, sports, entertainment and } \\
\text { recreation }\end{array}$ & $4-5-1$ & 8,77 E-08 & $2,71 \mathrm{E}-03$ \\
\hline provision of other services & $4-6-1$ & 4,10 E-07 & $1,18 \mathrm{E}-03$ \\
\hline
\end{tabular}

According to the results of the study we can conclude that the imbalance between supply and demand in the labor market is observed in almost all types of economic activity. It is revealed that the trend of redundant vacancies is observed not only in education but also in such activities as water supply, sewerage and waste management, transport, warehousing, postal and courier activities.

The number of unemployed persons exceeds the number of job openings in such sectors as agriculture, forestry and fisheries, construction, wholesale and retail trade, repair of motor vehicles and motorcycles, financial and insurance activities.

That is why the need to forecast supply and demand for specialists by type of economic activity is of particular importance.

To investigate how many times the current level of registered unemployed and the number of vacancies have changed compared to the previous period, their growth rates have been calculated. A noticeable decrease in the number of persons who had the status of unemployed was observed in agriculture, forestry and fisheries, mining and processing industries, financial and insurance activities, etc. 


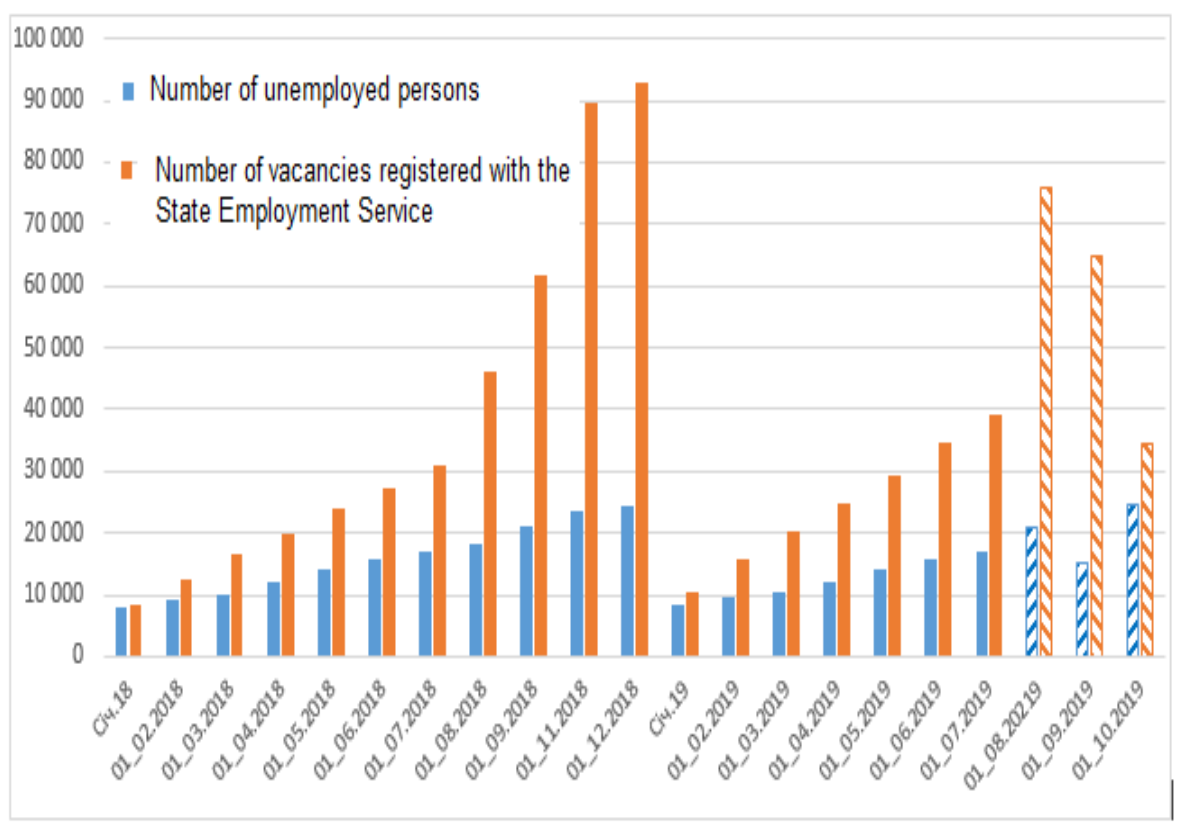

Fig. 6. Number of unemployed persons and vacancies in education for the years 2018-2019, including the forecast August-October 2019

A survey of the growth rate for the number of vacancies registered with the State Employment Service showed that in 2019 compared to 2018, the number of vacancies declined in the mining and quarrying, manufacturing, financial and insurance industries.

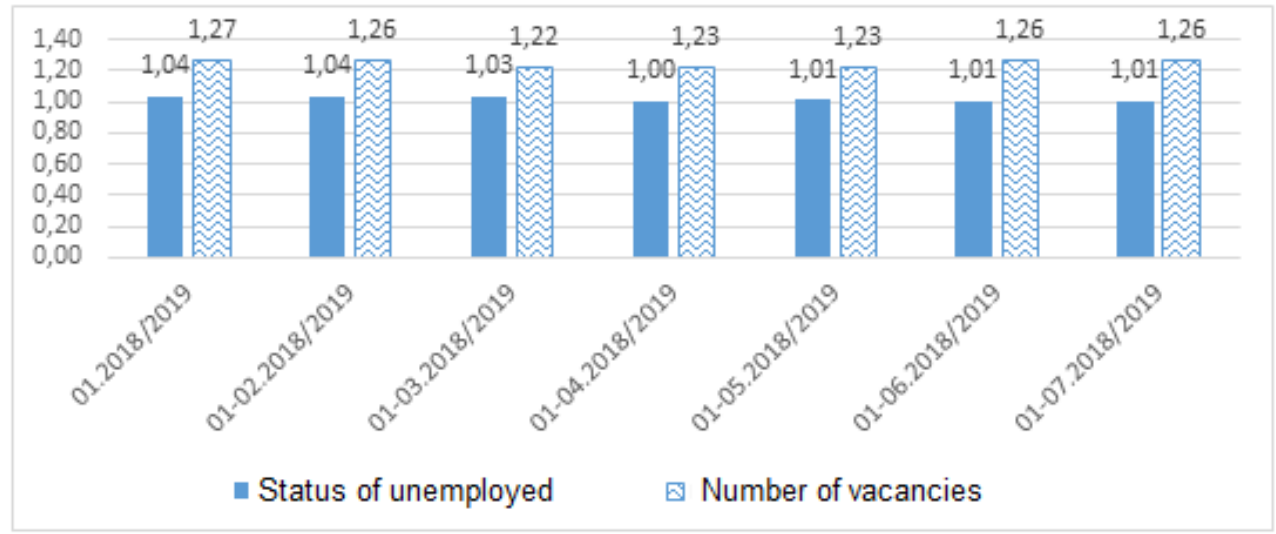

Fig. 7. Dynamics of growth (decrease) in education 2018-2019 
The projected figures for the number of vacancies for August-October 2019 indicate a decrease in vacancies in agriculture, forestry and fisheries, financial and insurance activities, wholesale and retail trade, public administration and defense, compulsory social insurance. All other types of economic activity are projected to increase the number of jobs.

For the education sector in 2018-2019, the dynamics of employment vacancies registered outstripped the growth rate of unemployed persons (Fig. 7). The situation can be explained by the low wages of educators, high inflation, migration, the search for better working conditions.

The forecast values for August-October 2019 show an increase in the number of people who have had the status of unemployed and a decrease in the number of vacancies (Fig. 8)

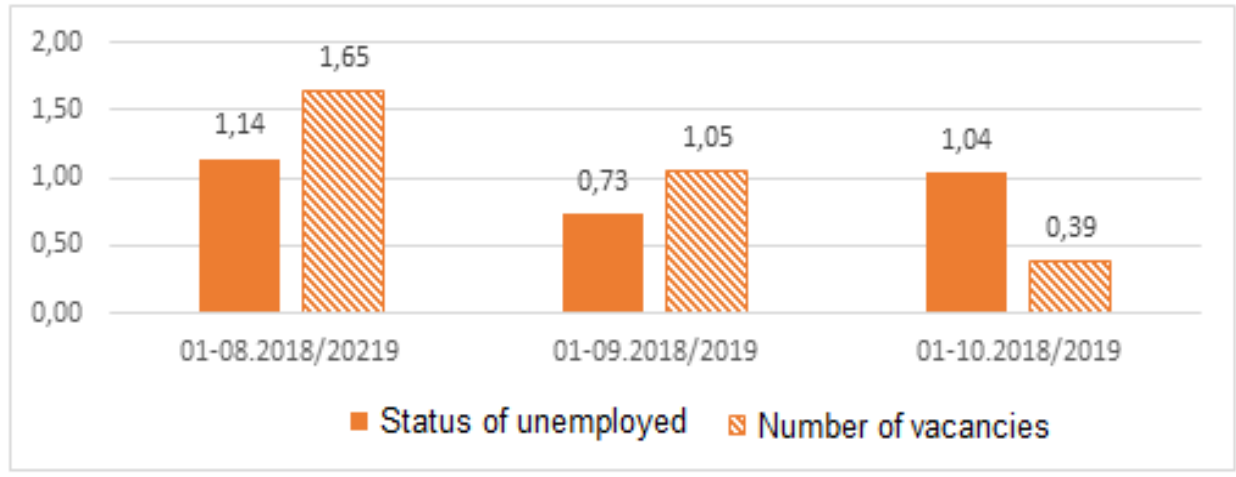

Fig. 8. Forecasted growth rates in education for August-October 2019

The labor market, as an important subject of innovative development, plays a key role in ensuring the stable competitiveness of Ukraine's economic system and is the basis for the vital provision of all segments of society. In our opinion, the development of the labor market is one of the strategic tasks of implementing the innovative model of economic development of Ukraine.

Using the proposed method of short-term forecasting of labor supply and demand, it is possible to obtain results on the basis of which it is advisable to develop effective measures to prevent structural unemployment arising from the structural demand deficit experienced by certain sectors of the economy. In addition, in order to reduce the imbalance between supply and demand in the domestic labor market, it is advisable to adopt at the state level appropriate normative documents that would determine the measures for the development of the system of forecasting demand and supply of labor. Such a set of measures will provide a medium-term forecast for the development of the labor market as a whole; encouraging young people to acquire professions and mastering the professions whose needs will be anticipated; reform of the public employment service towards a customeroriented service, and one that offers a wide range of services and training tailored to the needs of the economy in general and in each region individually.

1. Bliznyuk, V.V. (2016). The Ukrainian labor market: historical challenges and new challenges. Ukrainian society, 3 (58), 58-71. 
2. Lisogor, L.S. (2012). Forecasting the development of the labor market in Ukraine: problems and prospects. Labor market and employment of the population, 1, 54-56.

3. Pryymak, V.I., \&Wozniak, O.G. (2012). Econometric models for forecasting labor supply and demand in Ukraine. Scientific Bulletin of NLTU of Ukraine, 22.11, 313319. nbuv.gov.ua. Retrieved from http://nbuv.gov.ua/UJRN/nvnltu 201222 (accessed 28/08/2019)

4. GS Kabachenko Regulation of the labor market in the conditions of transformation of the structure of employment dis. (2017). ... Cand. econom. Sciences: 08.00.07. Donetsk National University named after Vasyl Stus. Vinnitsa.

5. Pryymak, V.I., \& Skurupka D. (2011). Neural networks in labor market management. Actual problems of regional economy development, 7, 260-266.

6. Osovsky, S. Neural networks for information processing (2002). Moscaw: Finance and Statistics.

7. Mishchuk, N.V.(2019). Organizational and economic regulation of the development of education in the system of youth competitiveness in the labor market of Ukraine. diss. ... Cand. econom. Sciences: 08.00.03. Ivan Franko National University of Lviv. Lviv.

8. Pryima, S.S., Vovk, R.V., \& Vovk V.R. Using Artificial Neural Networks to Forecast Stock Market Indices (2019). XIth International Scientific and Practical Conference on Electronics and Information Technologies (ELIT), Lviv, Ukraine, September 16 - 18.

9. State Employment Service: Website. www.dcz.gov.ua. Retrieved from https://www.dcz.gov.ua/analitics/68.

\section{References}

1. Bliznyuk V.V. The Ukrainian labor market: historical challenges and new challenges. Ukrainian society. 2016. No. 3 (58). Pp. 58-71.

2. Lisogor L.S. Forecasting the development of the labor market in Ukraine: problems and prospects. Labor market and employment of the population. 2012. № 1. S. 54-56.

3. Pryymak V.I., Wozniak OG Econometric models for forecasting labor supply and demand in Ukraine. Scientific Bulletin of NLTU of Ukraine. 2012. Iss. 22.11. P.313319. URL: http://nbuv.gov.ua/UJRN/nvnltu_2012_22 (accessed 28/08/2019)

4. GS Kabachenko Regulation of the labor market in the conditions of transformation of the structure of employment dis. ... Cand. econom. Sciences: 08.00.07. Donetsk National University named after Vasyl Stus. Vinnitsa. 2017. 247 p.

5. Pryymak V.I., Skurupka D. Neural networks in labor market management. Actual problems of regional economy development. 2011. Iss. 7. P.260-266.

6. Osovsky S. Neural networks for information processing. M.: Finance and Statistics, 2002. 344 p.

7. Mishchuk N.V. Organizational and economic regulation of the development of education in the system of youth competitiveness in the labor market of Ukraine. diss. ... Cand. econom. Sciences: 08.00.03. Ivan Franko National University of Lviv. Lviv. 2019. $250 \mathrm{p}$.

8. Pryima S.S., Vovk R.V., Vovk V.R. Using Artificial Neural Networks to Forecast Stock Market Indices // 2019 XIth International Scientific and Practical Conference on Electronics and Information Technologies (ELIT), Lviv, Ukraine, September 16 - 18, 2019.- p.108-112.

9. State Employment Service: Website. URL: https://www.dcz.gov.ua/analitics/68. 


\title{
НЕЙРОМЕРЕЖНЕ ПРОГНОЗУВАННЯ ПОПИТУ ТА ПРОПОЗИЦІЇ НА РИНКУ ПРАЦІ УКРАЇНИ ЗА ВИДАМИ ЕКОНОМІЧНОЇ ДІЯЛЬНОСТІ
}

\author{
Н. Міщук, С. Прийма
}

\author{
Львівський національний університет імені Івана Франка \\ 79008, м. Львів, проспект Свободи, 18 \\ e-mail:mishchuk_n@ukr.net,sv_pryyma@ukr.net
}

Розглянуто нові підходи до регулювання ринку праці, зокрема дослідження та прогнозування попиту і пропозиції робочої сили за видами економічної діяльності. Досліджено, що дисбаланс між попитом і пропозиціє на ринку праці спостерігається майже у всіх видах економічної діяльності. Встановлено істотність впливу сезонного фактору на процеси економічної активності населення.

Для ефективного управління ринком праці недостатньо знати його теперішній стан і те, як цей стан змінювався в минулому, необхідна інформація про траєкторію розвитку цього ринку у майбутньому. Тобто разом з оцінюванням стану й динаміки ринку праці потрібно мати прогноз попиту, пропозиції та інших характеристик цього ринку.

Для прогнозування кількості вакансій та кількості осіб, які мали статус безробітного за видами економічної діяльності запропоновано скористатись апаратом нейронних мереж. Нейронні мережі дозволяють моделювати лінійні та нелінійні залежності, мають здатність до узагальнення і виділення прихованих залежностей між вхідними і вихідними даними, що дає змогу побудувати адекватну математичну модель.

Вхідними факторами моделі для прогнозування кількості безробітних та кількості вакансій використано ряди даних Державної служби зайнятості за три роки помісячно 3 січня 2016 року по лютий 2019 року. Отримано прогнозні значення рівня зайнятості та безробіття на ринку праці України за видами економічної діяльності на серпеньжовтень 2019 року. Прогнозні значення можуть бути використані органами державного управління для вдосконалення політики регулювання ринку праці.

Запропонований підхід дасть змогу визначати заходи щодо стимулювання молоді до отримання професій і оволодіння спеціальностями, потребу в яких буде спрогнозовано з урахуванням потреб економіки взагалі і кожного регіону окремо.

Ключові слюва: ринок праці, зайнятість, безробіття, прогнозування, нейронна мережа, управління. 